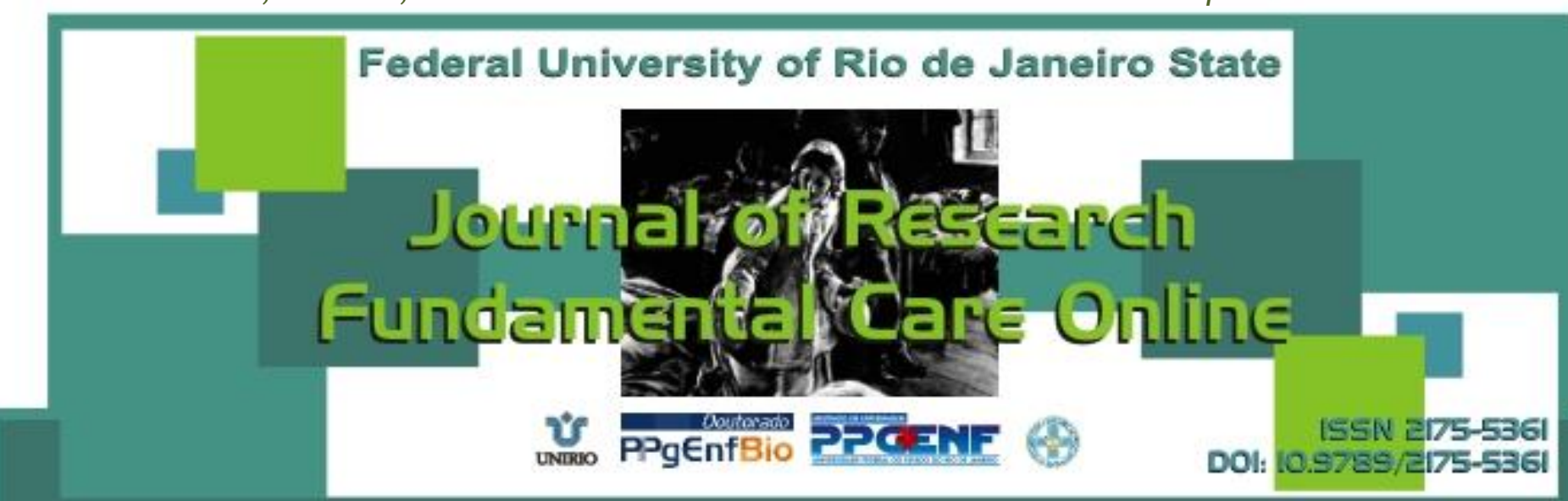

\title{
RESEARCH
}

Estresse e demais fatores de risco para hipertensão arterial entre profissionais militares da área de enfermagem

Arterial pressure control for nursing military professionals

El estrés y otros factores de riesgo entre profesionales militares de enfermería

Jorge Luiz Lima da Silva ${ }^{1}$, Rodrigo Pereira Lima ${ }^{2}$, Rodrigo Pereira Costa Taveira ${ }^{3}$, Felipe dos Santos Costa ${ }^{4}$, Rafael da Silva Soares ${ }^{5}$

\section{$\leadsto$ ABSTRACT}

Objective: Determine which risks factors for hypertension that military nursing professionals identify in their lifestyle; classifying blood pressure levels of professionals. Method: Quantitative, based on descriptive research. Results: This study included 40 military professionals in nursing. The following risks factors were identified for hypertension in the study population: using of hormonal contraceptives $(8.0 \%)$, smoking $(7.0 \%)$, alcoholic beverages $(2.0 \%)$, physical inactivity $(21.0 \%)$, stress $(25.0 \%)$, excessive salt intake $(11.0 \%)$, obesity $(8.0 \%)$ and high calorie and high protein diet $(18.0 \%)$. The classification of blood pressure of the subjects revealed that $70.0 \%$ showed pressure values considered normal or optimal, values between $12.5 \%$ and 17.5 $\%$ were considered borderline hypertensions prove. Conclusion: This study indicates the needs for changes in professionals' lifestyle, because the risks factors associated with blood pressure levels may contribute to the onset of hypertension into analyzed population. Descriptors: Blood pressure, Hypertension, Nursing, Military nursing.

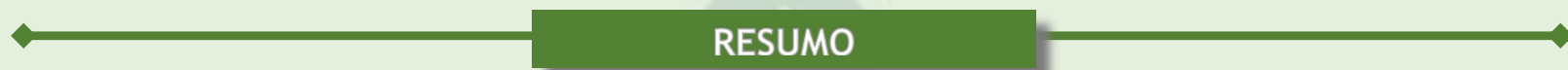

Objetivo: Verificar quais os fatores de risco para a HAS que os profissionais militares da área de enfermagem identificam em seu estilo de vida; classificar os níveis pressóricos dos profissionais. Método: Quantitativo, embasado em pesquisa descritiva. Resultados: Participaram do estudo 40 profissionais militares da área de enfermagem. Foram identificados os seguintes fatores de risco para a HAS na população estudada: uso de contraceptivos hormonais $(8,0 \%)$, tabagismo $(7,0 \%)$, etilismo $(2,0 \%)$, sedentarismo $(21,0 \%)$, estresse $(25,0 \%)$, consumo excessivo de sal $(11,0 \%)$, obesidade $(8,0 \%)$ e dieta hipercalórica e hiperprotéica $(18,0 \%)$. A classificação da pressão arterial dos sujeitos revelou que 70,0\% demonstraram valores pressóricos considerados normais ou ótimo, $12,5 \%$ valores considerados limítrofes e $17,5 \%$ comprovaram HAS. Conclusão: 0 estudo denota a necessidade de mudanças no estilo de vida dos profissionais, pois os fatores de risco associados aos níveis pressóricos podem contribuir para o aparecimento de HAS na população estudada. Descritores: Pressão arterial, hipertensão, enfermagem, enfermagem militar. \begin{abstract}
RESUMEN
Objetivo: Los factores de riesgo para la mpertension que los profesionales de enfermería militares identifican en su estilo de vida; clasificar a los niveles de presión arterial de los profesionales. Método: Cuantitativo, basado en una investigación descriptiva. Resultados: El estudio incluyó 40 militares profesionales en enfermería. Se identificaron los siguientes factores de riesgo para la hipertensión en la población de estudio: el uso de los anticonceptivos hormonales $(8,0 \%)$, el tabaco $(7,0 \%)$, alcohol $(2,0 \%)$, inactividad física $(21,0 \%)$, estrés $(25,0 \%)$, la ingesta excesiva de sal $(11,0 \%)$, la obesidad $(8,0 \%)$ y alta en calorías y dieta rica en proteínas de alto $(18,0 \%)$. Clasificación de la presión arterial de los sujetos reveló que $70,0 \%$ mostró valores de la presión que se consideran normales u óptima, los valores de $12,5 \%$ y $17,5 \%$ hipertensión limítrofe considerado demostró. Conclusión: El estudio indica la necesidad de cambios en el estilo de vida de profesionales, debido a que los factores de riesgo asociados a los niveles de presión arterial pueden contribuir a la aparición de la hipertensión en la población estudiada. Descriptores: Presión arterial, hipertensión, enfermería, enfermería militar.
\end{abstract}

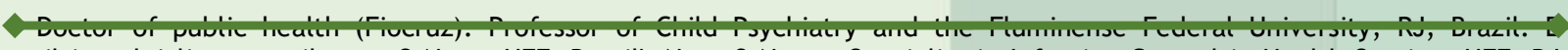
mail:jorgeluizlima@gmail.com 2 Nurse-UFF. Brazil's Navy 3 Nurse. Specialist in Infection Control in Health Services-UFF, RJ, Brazil 4 Nurse, Specialist in Public Health and Family Health UNIFESP, Brazil 5 Nurse, Municipal Souza Aguiar Hospital, Brazil 


\section{INTRODUCTION}

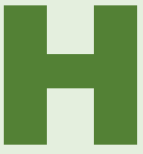

ypertension is defined as a systolic blood pressure greater than or equal to $140 \mathrm{~mm} \mathrm{Hg}$ and diastolic blood pressure greater than or equal to $90 \mathrm{~mm} \mathrm{Hg}$, in individuals who are not making use of antihypertensive medication. ${ }^{1}$ Is diagnosed when it detects high and sustained levels of blood pressure (BP) by as casual (random, casual). ${ }^{2}$

Data from the Ministry of health of Brazil shows that there are around 17 million people with hypertension, and $35.0 \%$ of the carriers have 40 years or more. It is estimated that $4.0 \%$ of children and adolescents are also carriers, showing that its appearance is increasingly early. High blood pressure is a serious public health problem in Brazil and in the world due to its morbimortality. ${ }^{1}$

According to the Ministry of health of Brazil, the systemic arterial hypertension (SAH) is one of the most important risk factors for cardiovascular diseases, cerebrovascular disease and kidney. Is responsible for at least $40.0 \%$ of deaths from cerebrovascular accident; $25.0 \%$ of deaths from coronary artery disease and, when associated to diabetes, is responsible for $50.0 \%$ of cases of ESRD. With the diagnostic criterion of HAS the figures mentioned above, the prevalence in urban Brazil adult population ranges from $22.3 \%$ to $43.9 \%$, depending on the city where the study was conducted. ${ }^{1}$

In relation to patient hypertensive, the motivation to avoid the abandonment of treatment is perhaps one of the most arduous battles that health professionals face. To further complicate the situation, it is important to remember that a large contingent of hypertensive also features other co-morbidities, such as diabetes, Dyslipidemia and obesity, which has important implications in terms of management of therapeutic actions required for control of a cluster of chronic conditions, whose treatment requires perseverance, motivation and continuing education. ${ }^{1}$

Almost always, accompany these findings progressively, injury to blood vessels with consequent organ changes targets as: brain, heart, kidney and retina. Generally, it is a silent disease: it doesn't hurt, it may not cause symptoms, however, can kill when symptoms occur, resulting from complications. ${ }^{3}$

Some authors are radicals in relation to disease, stating that the HAS is called a "silent killer" because it usually does not cause any type of symptom for many years until a vital organ is affected. ${ }^{4-5-6-7}$ These abnormally high pressures attend most often asymptomatic. High blood pressure can lead to injuries, sometimes irreversible human organism. Since the symptoms can appear only after years of injury to vital organs, the most effective measure to prevent the disease take the incapacity or even death is, without doubt, the prevention. ${ }^{8}$ 
The contribution of genetic factors to formation of HAS is well established in the population. However, so far, are nonexistent genetic variants that can be used to establish the individual risk of developing HAS. Improper living habits are also important: obesity, excessive sodium intake (in the form of table salt, or foods with high sodium content) or alcohol and physical inactivity can contribute to the onset of hypertension. Blood pressure also has direct and linear relationship with age, where the prevalence of SAH is superior to $60.0 \%$ in the age group above 65 years. In relation to the genre, although it is higher in men up to 50 years and flipping from the fifth decade of life global HAS prevalence between men and women is similar. With respect to ethnicity, SAH is twice as prevalent in individuals of different color of white. ${ }^{9}$

The BP measurement should be performed in all evaluation by doctors of any specialty or other health professionals. ${ }^{2}$ In that the nurse acts to control the HAS, where, in addition to the measurement of blood pressure, preventive health education action, the latter held in the nursing consultation. Health education can help these individuals to adapt to disease, prevent complications, and learn how to solve problems related to pathology.

Health education is a fundamental responsibility of nursing care, and is directed to the promotion, maintenance and restoration of health; disease prevention; and assistance to people to deal with the residual effects of the disease. ${ }^{10}$

A study identified risk factors in nursing workers of a general hospital where, $28.8 \%$ of technicians made use of tobacco, IMC and the stress level performed in higher level in hypertensive and auxiliaries were nurses (29.7\%). ${ }^{11}$

The military professional in the area of nursing, in addition to fit in the indexes of national incidence and prevalence, has a significant component that may trigger or precipitate the emergence of the disease. The literature search that preceded the construction of the work showed a lack of reference material on this group. Realize that professional military area has its own characteristics, such as the high risk of death (attributed principally to the cops), their own rigidity maintained by discipline and hierarchy, among other unique factors of these professionals as stress.

The military police of the State of Rio de Janeiro (PMERJ) "is a permanent institution, organized based on hierarchy and discipline, for the maintenance of public order in the State". The authority and the responsibility to grow according to the hierarchical level of its members. According to article 12, paragraph 2 of the Statute of the PMERJ (1981): "[...] the discipline is strict adherence to and full compliance with laws, regulations, standards and provisions for the police-military body and coordinate its regular functioning and harmonic, translating for the perfect line of duty on the part of each and every one of the components of that body ". ${ }^{12}$

Under the circumstances that are the military profession, this study seeks to relate the occupation of this distinguished professional class to the prevalence of SAH. These peculiarities, coupled to the stress factors inherent in the nursing profession described in the literature, boosted the achievement of the study.

On the exposed, is this study describe the risk factors related to HAS referred to by military healthcare professionals and sort the pressure levels of professionals according to the current consensus in relation to the risk factors identified. 
The way of life affects directly the risk factors, hence its relevance and thorough survey of habits that are considered harmful to health. It is necessary to know the lifestyle and contribute to it to be favorable to the maintenance of health and quality of life. ${ }^{3}$

By be asymptomatic in most of its course, its diagnosis and treatment are neglected and part of patients adhere to treatment, with low membership. Is of fundamental importance for the therapeutic process, and for the prevention of hypertension there is lifestyle changes. ${ }^{1.13-14}$

The drop-out rate and highest degree of lack of adherence to antihypertensive treatment grows as the greater the time elapsed after the start of therapy. Early detection and primary prevention are the most effective ways to prevent diseases and should be the main goals of health professionals. In it, nursing stands out, because it will use health education that is a feature of nursing care. ${ }^{2}$

Among the various activities that the nurse must play are: empowering the Trustees and community agents; play the nursing consultation, addressing issues such as risk factors, non-medicated treatment, adherence and potential complications to treatment and, when necessary, refer the person to a doctor; establish, with the team, strategies that can encourage (hypertensive and diabetic groups); request, during the nursing consultation, the minimum tests established in consensus and defined as possible and required by the team doctor. $^{1}$

The inclusion of other professionals, especially nutritionists, assistants, psychologists, dentist's partners, physical education teachers, is seen as very enriching, highlighting the importance of interdisciplinary action for the prevention and control of HAS. ${ }^{1}$

Adequate food, especially regarding the salt intake, weight control, physical activity, excessive alcohol use and smoking are risk factors that if not addressed and controlled properly, even with the continuous use of medicines not be able to achieve the desired levels of blood pressure. 1

With that, stresses the importance of studies that identify risk factors in specific populations, in order to bring the discussion to the academia and go back to the participants of the study results and mitigating proposals. 


\section{METHOD}

The subjects of the research were 40 military professionals of the Nursing Board of all categories (nurses, technicians and nursing assistants). The study scenario was the Hospital of the military police located in the municipality of Rio de Janeiro.

At first contact, were explained the purpose of the survey and presented the informed consent. Each participant filled in the document, as in the case of research involving human beings, the National Health Council (CNS Resolution 196/96 of October 16, 1996) requires that the subject is a member of the group to search for meet the study and give consent to the rules. This study was approved by the Committee of ethics in research with Human Beings at the University Hospital Antônio Pedro in the year 2005, registered under number $044 \backslash 06$ as well as was allowed by the superior military organs responsible for the hospital.

The instrument used was the form with script of questions structured with open and closed questions with four sections, divided by subjects. An initial section included the characterization of the subject that aimed to identify the age, gender, professional category and skin color. The next section asked about family history and if the professional was the bearer of HAS. If there were no relatives with hypertension on the participant's family, it should be noted the degree of relatedness. And if a carrier of the disease, should inform you if ever suffered hypertensive peaks and was drug treatment.

A third stage of collecting information addressed the risk factors for SAH, and participants should inform those who recognize in your lifestyle. In the last part of the questionnaire, was asked about the frequency of blood pressure measurement by subject.

After the interview, have been checked the blood pressure values. This measurement was performed without diagnostic claims, because according to the Ministry of health of Brazil, for the diagnosis in individuals with high in a calibration shall PA be repeated blood pressure measurements in different periods, before to characterize its presence. This study did not have diagnostic purposes, yet have been confirmed the values later in the next day's work. ${ }^{1}$ In addition to two measures of the PA, it is also recommended that the measurements be obtained in both upper limbs. And in case of difference, always use the higher pressure armprocedure adopted by researchers. ${ }^{2}$

The participants had their BP checked in a sitting position like recommend the said guidelines. Then each participant was told that BP should be reassessed, taking into consideration the following criteria provided by SAW confirmation of the values measured for $\mathrm{DBH}$. Additional information was provided about the risk factors and signs/symptoms of SAH in brochures created by the authors of the survey. ${ }^{2}$ 
It is worth noting that, except for the measurement of blood pressure performed at the end of the interview, all the information has been self-proclaimed by the subject, thus avoiding any deductions from the interviewer.

The forms were analyzed in order to correlate the variables found. This kind of analysis made it possible to evaluate the relationship between two variables, a risk factor (independent variable) and a disease (the dependent variable).

For data analysis, first, were cleared the information pertaining to the risk factors associated with HAS-both not modifiable, as modifiable-then blood pressure levels were classified according to the values proposed by the Brazilian society of hypertension (SBH) and the Brazilian society of Cardiology (SBC). Later, those who showed high levels of PA had their risk factors grouped and scheduled. The next step was to analyze the findings related to the declared carriers HAS and its relation to the treatment of the disease. 9.15

The data were organized into charts and numerical tables for easy interpretation. Sought to relate the findings with the theoretical reference on the topic, emphasizing the importance of identifying the risk factors for HA.

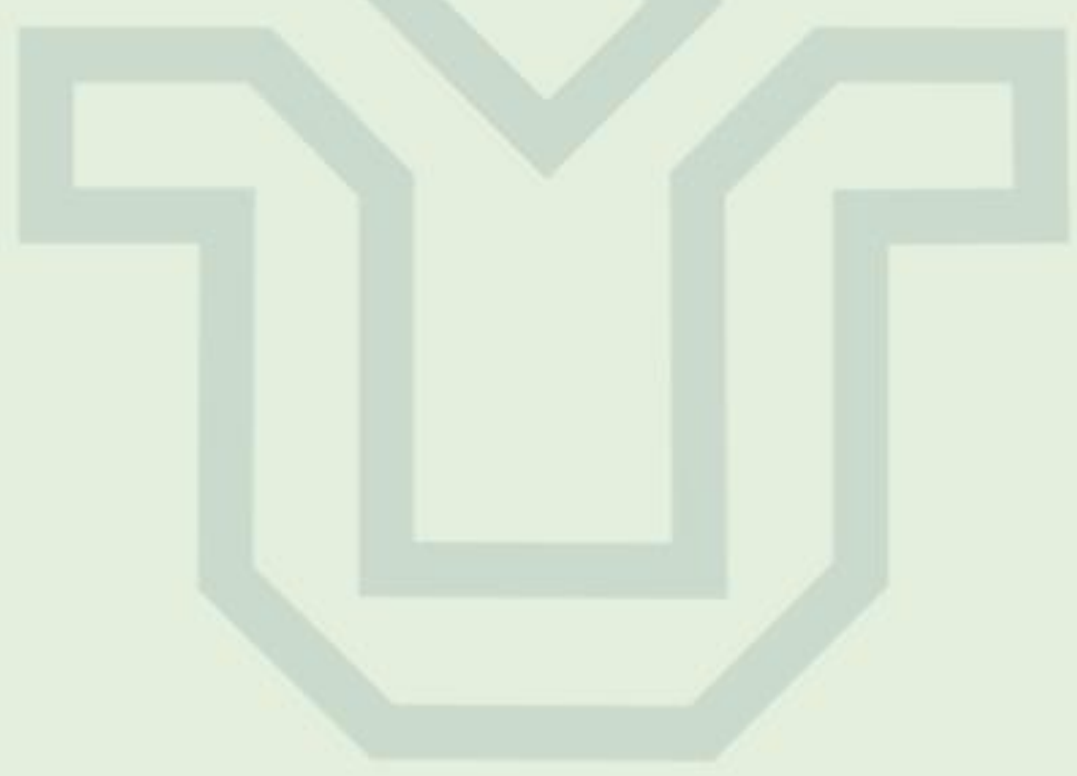




\section{RESULTS AND DISCUSSION}

Of the 40 military health care professionals who participated in the study, 12 subjects (30.0\%) had between 20 and 30 years, 22 (55.0\%) between the ages of 31 and 40 years and only $6(15.0 \%)$ were over 41 years. With regard to gender, 25 professionals $(62.5 \%)$ were women, while only 15 (37.5\%) were men. Professionally, 10 subjects (25.0\%) were nurses, 25 $(62.5 \%)$ nursing technicians, and 5 (12.5\%) nursing assistants.

Noted the high proportion of nursing technicians and considerable portion of nurses in the study population. The number of professionals has remained as the general pattern reported by Daher (2000), where it states that nursing occupies, on the team of health, approximately $50.0 \%$ of the workforce in health where those with higher level education occupy the lowest percentage. ${ }^{16}$ according to the Federal Council of Nursing, nursing professionals all over Brazil are 1,449,583, where that total correspond to 287,119 professional nurse's category (19.81\% of the total), technical 625,862 nursing professionals (43.18\%), nursing assistants professional 533,422 (36.80\% of the total), 106 professional midwives $\left(0.01 \%\right.$ of the total) and informed Professional $3,074\left(0.21 \%\right.$ of the total). ${ }^{17}$

It was found that $32.5 \%$ of participants have shown pressure values considered normal, $50.0 \% 17.5 \%$ values considered border proved HAS. Of these, $15.0 \%$ showed HAS $2.5 \%$ and 1 stage HAS stage 2.

In Brazil, the Health Ministry's data, in 2002, show prevalence, among the largest of 20 years, of 11.0 to $20.0 \%$. We see, then, the closeness of the results of this study of national statistics. 18

In general, the two goals of systolic and diastolic recognized by Brazilian guidelines, American, Canadian and European are below $140 / 90 \mathrm{mmHg}$ for the population of low risk hypertensive and 130/80 mmHg for diabetic patients or those with kidney disease. ${ }^{19}$

Within the framework of military police of the State of Rio de Janeiro (PMERJ) in active service, the nursing part of the auxiliary Board of health. However, nursing assistants and technicians are part of the body of squares, being the difference between these categories the hierarchical degree. The nurse, however, by owning top level, is part of the official framework of the PMERJ, responsible for the exercise of functions of command, leadership and direction. ${ }^{12}$

\section{Risk factors associated with Hypertension (SAH)}

The determination of the interaction depends on complex HAS factors. These factors generally are called risk factors. These characteristics can be defined as integral aspects of human life, contributors to a dangerous result, in this case the disease itself. 
The risk factors identified were divided into two major subcategories: non modifiable and modifiable. Non-modifiable factors are biological aspects beyond the capacity of the individual modification. On the contrary, the modifiable risk factors are liable to modification and the subject control them by hard and determination. Understanding the mutable and immutable characteristics of HAS is necessary to discuss the interaction between the various aspects that make up the complex syndromic of the disease. ${ }^{1,2.8}$

\section{Modifiable risk factors}

Were considered in this study as modifiable risk factors age, sex, skin color and family history for the disease. These factors are out of the way of life, however the influence in the emergence of the disease, due to the genetic aspect; soon, cannot be overlooked in the analysis of PA.

The first risk factor contained in biological aspects analyzed is the age. Age is an important risk factor that contributes to the appearance of HAS, due to changes in smooth muscle and connective tissue of vessels, as a result of the aging process. ${ }^{8}$ Can show that the worker over 40 years is a priority for intervention actions favoring the primary and secondary prevention of HAS and DM. These actions, you should give special attention to food and the practice of physical exercises, facilitating the control of obesity and Dyslipidemia. ${ }^{20}$

Table 1 shows the percentage distribution of the age of the subjects with an average age at which the disease begins to show the signs and symptoms or, in some cases, damage to target organs, since the natural history of HAS have direct correlation with individuals over the age of 40 years. Of the total of 40 respondents, 25 were female $(62.5 \%)$ and only 15 males (37.5\%).

The variable age, when correlated with sex demonstrates a certain degree of mutual influence with respect to HAS. SAH is more prevalent in men up to about 45 to 50 years the when, so to prevail in women due to hormonal changes related to menopause. ${ }^{8,20,21}$ with regard to gender, the prevalence was $30.0 \%$ in women and $35.8 \%$ in men, being similar to that of other countries. According to this study, in a systematic review conducted in 2003 to 2008 , 4435 countries studies, one can see a global prevalence of $37.8 \%$ in men and $32.1 \%$ in women. 22

Table 1: modifiable risk factors for HAS cited by military professionals in the field of nursing in 2006. 


\section{MODIFIABLE RISK FAC
Age of professionals
Less than 40 years}

Less than 40 years

More than 40 years

Sex

Male

Female $\begin{array}{ll}8 & 20.0 \\ 32 & 80.0\end{array}$

3280.0

$\begin{array}{ll}15 & 37.5\end{array}$

$\begin{array}{ll}25 & 62.5\end{array}$

Skin color auto-referred

$\begin{array}{lll}\text { White } & 19 & 47.5 \\ \text { Black } & 4 & 10.0 \\ \text { Parda } & 12 & 30.0 \\ \text { Brunette } & 4 & 10.0 \\ \text { Light brunette } & 1 & 2.5\end{array}$

$\mathrm{n}=$ number of times that stated the risk factor for health professionals

In both sexes the frequency of hypertension grows with increasing age, and young men have higher blood pressure than women, but after the middle age this Board reverses. ${ }^{8}$ In another study, heart failure (HF) occupied the third position in emergency cardiovascular care of SUS in Salvador, where $55.0 \%$ of men and $67.5 \%$ of women presented PAS $\geq 140 \mathrm{mmHg}$ and $46.0 \%$ men and $65.5 \%$ of women had PAD $\geq 90 \mathrm{mmHg}$, showing an increased frequency of women with PA above considered normal. ${ }^{23}$

Nursing is a profession overwhelmingly female. Historically, the professions that coalesced higher proportion of female workforce had correlation with the length of the reproductive function of women, such as teaching and nursing. This social devaluation of some occupations ends up harming the entire production process of nursing that has most of their female workforce. Add to that the triple working day to which they are subjected many women: productive work remunerated domestic work, care of children and workers and work on the generation of new social subjects without male participation. ${ }^{24}$

In relation to HAS some risk factors are unique to women. For example, the use of hormonal contraceptives and menopause. The effects of menopause on blood pressure are difficult to evaluate, already suffering from various factors, such as age, body mass index, smoking and social class. It is believed that the ovarian hormones might be responsible for the lower blood pressure in women pré-climacteric and also by the increased blood pressure in menopausal women. ${ }^{25}$

Other non-modifiable risk factor examined is the color of the skin. On the characterization of the skin color of the subject, we opted for an approach free of "preconceptions". To do this, in the interview, the skin color issue asked the professionals a self-definition on the variable investigated.

The Brazilian population if auto define through almost two hundred colors. The color of the skin, therefore, is a subjective data that depends on the self-identification of the individual. ${ }^{26}$

In a study on the impacts of HAS and its risk factors in black ethnicity, characterized the group, selecting to be sampling just individuals declared blacks and Browns. The authors infer that the rates of morbidity and mortality related to the harms of HAS are higher, 
especially in the so-called "social minority", among them the black ethnicity. Based on the categorization of the proposal, and in view of the similar features as regards the skin color of the respondents declared Brown and Brown with light brown color characteristics, the superiority of this group in all, amounting to $52.5 \%$ of the total, against only $47.5 \%$ of individuals declared white. ${ }^{27}$

PA levels tend to be higher, inexplicably, in people of dark skin color, the development HAS more early occurs and severe in comparison to the rest of the population. There are, in the literature on the subject, some possibly mechanisms responsible for these differences in different ethnic groups, as for example, the lowest renal excretion of sodium and potassium by Blacks. However, all the explanations are still incipient. ${ }^{8}$

The prevalence and severity of hypertension in blacks, are larger, which may be related to ethnic and/or socioeconomic factors. In Brazil a microphone is prevalent, and may differ from the dark as to the characteristics of hypertension ${ }^{1}$. In relation to miscegenation, in Brazil, is not known with accuracy, its impact on SAH. ${ }^{2}$

The last non-modifiable risk factor for SAH approached was the family history. It is important to note that the total of 40 participants, 31 were at least a relative hypertension. Ganging up individuals who have father and/or mother with hypertension, a portion of $63.0 \%$, demonstrating a high degree of genetic inheritance.

Of the factors involved in physio pathogenesis of hypertension, a third of them can be attributed to genetic factors. Cite as an example the blood pressure regulatory system and sensitivity to salt. ${ }^{28}$ the great importance of heredity in the appearance of HAS with respect to the correlation with the other risk factors for the disease. "Genetic predisposition favors interactions with other risk factors, expressing the HAS more frequently in individuals with a family history positive". ${ }^{8}$

\section{Modifiable risk factors}

The main recommendations for primary prevention of nonmedicinal HAS are: control of the consumption of salt and alcohol, healthy nutrition, potassium intake and combating the sedentary lifestyle and smoking. ${ }^{2}$

The modifiable risk factors identified in the study were: use of hormonal contraceptive, smoking, alcoholism, sedentary lifestyle, stress, salt intake, obesity and food/hyper protein hydroxyglutarate (table II).

As well as the characterization by skin color, the identification of modifiable risk factors was also auto declare by the subject. The risk factors have a direct relation with the lifestyle of each person. Rouquaryol "defines lifestyle habits and behaviors auto determinate, acquired culturally or socially, individually or in group. ${ }^{29}$ These habits and behaviors define, in the long term, the expectation of life of every human being. The quality of life is directly related to the perception that each person has of themselves and others, the world is his back, which may be evaluated by appropriate criteria, such as education, training, professional activity, skills acquired, personal resilience, optimism, personal needs and health. ${ }^{30}$ next, will be described the risk factors mentioned by participants in their lifestyle, each participant could refer to more than one item. 
Table 2: Modifiable risk factors for HAS cited by military professionals in the field of nursing in 2006.

\begin{tabular}{lll}
\hline MODIFIABLE RISK FACTORS & $\mathrm{n}$ & $\%$ \\
Hormonal contraceptive & 9 & 8.0 \\
Smoking & 3 & 7.5 \\
Alcoholism & 1 & 2.0 \\
Sedentary lifestyle & 8 & 21.0 \\
Stress & 10 & 25.0 \\
Salt intake & 4 & 11.0 \\
Obesity & 3 & 8.0 \\
Food and hyper protein hydroxyglutarate & 7 & 18.0 \\
$\mathrm{n}=$ number of times that stated the risk factor for health professionals
\end{tabular}

\section{Hormonal contraceptive}

Of the 25 women participating in the study, 9 of them $(36.0 \%)$ made use of hormonal contraceptive. In one study, the Nurse's Health Study followed prospectively 68,297 nurses Normotensive in young for a period of four years, in order to monitor the development of hypertension. It has been found that nurses who used oral contraceptives showed $80.0 \%$ more likely to develop hypertension when compared to those who had never used this form of contraception. However, with the withdrawal of the medication, this risk was eliminated almost completely. ${ }^{31}$

Another cross-sectional study examined the association between oral contraceptives and blood pressure control in hypertensive women 171 where noted that the guys who made use of oral contraceptives had worse control of PA and tended to have more severe hypertension than those who made use of other contraceptive practices or not used. ${ }^{32}$

According to the Ministry of health of Brazil, the HAS is two to three times more common in users of oral contraceptives, especially among the elderly and obese. ${ }^{1}$ Oral contraceptives $(\mathrm{OC})$ should not be used by women smokers over 35 years, especially if carrying HAS not controlled, Systemic Lupus Erythematosus and previous history of thromboembolic disease, because its use is associated with cardiovascular complications bigger, although not frequent, HAS induced by co. must monitor PA every six months or when the woman does not feel well and still If the PA rise significantly, suspend its use, providing another alternative contraceptive method. If there is another form of contraception application, keep the oral contraceptive and to consider the use of antihypertensive drugs to PA control. ${ }^{2}$ the III Brazilian Consensus Hypertension considers the hormonal contraceptives as possible causes of hypertension. It also States that "Although there is no formal contraindication the use of oral contraceptives should be avoided in women over 35 years old and obese at higher risk for hypertension. In women over 35 years and irreducible, the oral contraceptive smokers are formally contraindicated [...] ". 4

Based on the recommendations of the third $\mathrm{CBH}$, about the contraindications of contraceptives, noticed that the 9 women who declared make use of the medicine, a smoked and other if defined as obese. The age of these women was at an average of 31 years. ${ }^{4}$ 
The oral hormonal contraceptives can induce HAS, but the interruption of the use of the medicine for about three months, it tends to restore blood pressure to normal levels ${ }^{33}$. If the PA does not return to normal values within three months, properly handle and carry out the appropriate diagnostic research. ${ }^{2}$

\section{Smoking}

The proportion of smokers among respondents was 7.0\%. Tobacco use was found superiorly in men. Of the total number of smokers, $87.5 \%$ were men and $12.5 \%$ women. However, smoking is more related to the elevation of the PA in women than in men. In the assessment made by MAP, the PA systolic hypertensive patients who smoke has been considerably higher than in non-smokers, showing the important transitional hypertensive effect of smoking. This shows that the hypertensive patients who smoke should be strongly encouraged to abandon this habit through advice and specific therapeutic measures. ${ }^{1}$

The III CBH points out that "while the blood pressure and heart rate rise during the Act of smoking, prolonged use of nicotine is not associated with a higher prevalence of hypertension. In addition to the increased risk for coronary heart disease associated with smoking, individuals who smoke more than a pack of cigarettes a day are 5 times greater risk of sudden death than nonsmokers. Additionally, smoking contributes to the adverse effect of reducing the therapeutic serum lipids and induce resistance to the effect of antihypertensive drugs. " Soon, smoking can contribute to a bad prognosis for hypertension and its harms. ${ }^{4}$

Even if you don't consider tobacco use as a risk factor, on the other hand, smoking is associated with many deaths from cardiovascular diseases in Brazil. Is proven to be a real risk factor not only for lung cancer, emphysema and bronchitis, as well as for coronary heart disease, cerebral and peripheral vascular. The vasoconstrictor factor is the more relevant, as well as accelerate the process of atherosclerosis. In relation to coronary disease, approximately $40 \%$ of the increase of risk disappear after five years of interruption of the habit, however, be required several years more to be achieved levels of someone who never smoked. 34

Nicotine is harmful to the body, because it promotes the release of catecholamine's, which increase heart rate, blood pressure and peripheral resistance. Also increases the organic capacity in forming clots and decreases its function to destroy them. ${ }^{33}$

\section{Alcoholism}

As well as the use of tobacco, the consumption of alcoholic beverages is very common in Brazil. However, in the population studied, only $2.0 \%$ demonstrated intake of alcoholic beverages. The fact that the interview had been held in a military work environment may have influenced in the response. Alcohol consumption raises the PA so acute as chronically. 35 
"Consumption patterns and behavior are the main risk factors for $\mathrm{SAH}$, including excessive consumption of alcoholic beverages". ${ }^{8}$

Increased rates of alcohol raise blood pressure slowly and steadily, at a rate of $2 \mathrm{~mm}$ $\mathrm{Hg}$ for each $30 \mathrm{ml}$ of ethanol ingested daily, but when consumption is suspended, the pressure levels return to normal. ${ }^{33}$

The alcoholism if not prevented, must be controlled. Consumers of alcohol are instructed to ingest alcohol in a limit of $30 \mathrm{~g}$ alcohol/day $=1$ bottle of beer $(6.0 \%$ alcohol, 650 $\mathrm{ml})=2$ glasses of wine $(12.0 \%$ alcohol $150 \mathrm{ml}) 2$ dose $=(40.0 \%$ alcohol $.50 \mathrm{ml})$ of distillates (whisky, vodka, brandy), with half of that amount allowed for women. This guidance was made therefore in individuals with hypertension, alcohol consumption, and depending on the dose, although reducing the PA, causes high a few hours after consumption. ${ }^{2}$

\section{Sedentary lifestyle, eating habits and obesity}

Sedentary lifestyle, eating habits and obesity precarious walk together in the opposite direction. Therefore, it is nearly impossible to analyze a separate from the other two. The sedentary lifestyle coupled with the consumption of food calorie and hyper protein tends to produce obesity. Because they are closely linked, these three aspects of the lifestyle were analyzed looking for a direct relationship.

Compared to sedentary, $21.0 \%$ of the subjects consider this risk factor as being part of your lifestyle, being the second most declared by participants $A$ and study identified when $27.7 \%$ were with cholesterol level above $200 \mathrm{mg} / \mathrm{dl} .{ }^{11}$ The sedentary lifestyle is one of the most important cardiovascular risk factors in modern societies. The technological revolution brought about by increments has eased the lives of individuals around the world, in the same proportion that brought the indulgence and physical inactivity. The remote control, the elevators, the power Windows of cars are some examples present in everyday life. ${ }^{25}$

As for the food, $18.0 \%$ of the subjects to recognize as being and hyper protein hydroxyglutarate. Hardly, nowadays, people eat lunch in your House healthy food as a few years ago. In part, this is due to the rush of modern life and massive inclusion of women in the labour market. Instead of feeding correctly, people choose to do snacks, mostly, caloric (empty calories) and with excess fats. A balanced diet should contain low fat, especially saturated, low-cholesterol and sodium and high in potassium and fiber. ${ }^{36}$

The diet plays a major role in the control of hypertension. The diet with lower sodium content ( $<2.4 \mathrm{~g} /$ day, equivalent to 6 grams of sodium chloride) based, for example, in fruits, vegetables and whole grains, as well as reduced amount of saturated fats, for example, proved to be able to reduce blood pressure in hypertensive patients. ${ }^{1}$

The obese dating back $8.0 \%$ of the total number of subjects of research. The Ministry of health of Brazil States that excess weight is a predisposing factor for SAH. An estimated 20.0\% 30.0\% prevalence of SAH can be explained by this Association. Central obesity or Android, characterized by distribution of fat located predominantly in the abdomen, appears to be a predictive factor for cardiovascular disease than widespread obesity, since it is associated with insulin resistance and high blood pressure. The decrease in caloric intake leads to weight loss and reduction in blood pressure, which is explained by the fall of insulin, 
reduced sensitivity to sodium and decreased activity of the autonomic nervous system, sympathetic. ${ }^{1}$

Research on occurrence of hypertension in military of the Brazilian air force (FAB) showed that among the obese subjects, the rate was double the determined between individuals with overweight and triple that of individual's eutrophic. ${ }^{37}$

Taking obesity as a product of the interaction between physical inactivity and precarious food habits, the data obtained were analyzed in order to verify the Association of obesity with the other two factors.

Table 3: Association between risk factors

\begin{tabular}{ll}
\hline OBESITY, PHYSICAL INACTIVITY AND POOR NUTRITION & $\%$ \\
\hline Obesity + sedentary lifestyle & 67.0 \\
Obesity + poor diet & 78.0 \\
Obesity + sedentary lifestyle + bad-food & 44.0 \\
\hline
\end{tabular}

Of the total of $67.0 \%$ obese, sedentary, $78.0 \%$ showed claim to have food and $44.0 \%$ and hyper protein hydroxyglutarate showed have all three risk factors associated with your lifestyle. Note, therefore, although a small number of obese among the study population, a close relationship between unbalanced eating habits, lack of exercise and excess weight. The three independent risk factors are considered as predictive for SAH. Epidemiological studies indicate that obesity is an important and independent risk factor for hypertension. Considering the triple Association of factors, realize the dangers to which it is exposed the obese population studied. ${ }^{38}$

"The chronic physical exercise of low to moderate intensity causes changes important autonomic end up influencing, particularly, pressure levels. For this reason, regular physical exercise should be included as a non-pharmacological behavior in the treatment of hypertension ". 39

The prevalence of hypertension among individuals who practiced physical activity regularly was $52.0 \%$ lower compared with sedentary individuals. ${ }^{37}$

The physical activity recommendation is based on using parameters of frequency, duration, intensity and how it is performed. Where, physical activity should be practiced for at least 30 minutes, taking a moderate intensity on most days of the week in a continuous or accumulated. It should be noted that the effect of moderate-intensity activity carried out in a way that's accumulated performed continuously, i.e. 30 minutes can be performed in a single step or in two of 15 minutes or up to three 10-minute sessions. ${ }^{1}$

Obese individuals should start regular exercise programs, provided they have undergone a prior clinical evaluation and its interruption should occur in the presence of symptoms. In hypertensive individuals, the training should not occur if the systolic and diastolic pressure are in excess of 160 and/or $105 \mathrm{mmHg}$, respectively. ${ }^{2}$ In addition to lower blood pressure, exercise can greatly reduce the risk of coronary artery disease, stroke and mortality. In addition, should start eating balanced practices and with moderate levels of fats, cholesterol and sodium. 
Stress

Stress is defined as a "relationship between the person and the environment that is perceived by the person like overloading or overcoming their resources and endangering their well-being". ${ }^{40}$ the different ways in which individuals perceive, interpret and react to factors considered stressful condition variation in behavioral adaptation and determine who reacts in a manner unsatisfactory, becoming hypertensive. So, people may react differently, so that a succession of stressful events can be intolerable for a person and bearable to another. In this way, to conceptualize the stress you have to consider the properties of the person in relation to the environment. ${ }^{3}$

Of all risk factors declared, the stress took first place denoting $25 \%$ of the total professionals. Stress can raise blood pressure, but it's not proven its role in the genesis of hypertension. An important consideration with regard to tensions at work is the question. The stress was cited as part of the lifestyle by $72 \%$ of women and $67 \%$ of men. In research, pointedif $19.1 \%$ as stressed, showing a value similar to that of the study. ${ }^{11}$

Stress features a large incidence in both sexes, but is higher in women. This can be explained by the issue of triple workday that decreases your leisure time and prevents them to enjoy moments of relaxation.

Two studies on cardiovascular reactivity, being one with 58 patients with $\mathrm{SAH}$ and another with 80 adults, showed that hypertensive displays significant pressure increases to be subjected to experimental sessions of emotional stress. Since the last study showed a greater pressure increase when the hypertensive was taken to express directly their feelings. 41

It is noticed that there are several modes of interpretation the stress and the consequences of this. Notes on reports that stress can be defined as a symptom of illness or otherwise, as the causal agent of the disease. ${ }^{42}$

In this way, urge the need to perform works that emphasize the role of nurses, as well as all health professionals, prevention and early detection of high blood pressure and decrease the stress at work. ${ }^{43}$

The journey of the nursing Professional is stressful due to the own characteristics of the work. When it brings focus to the military professionals, one realizes that the rigidity and hierarchy can influence even more the stress of a trader and, therefore, contribute to changes in blood pressure levels, because "there are numerous reasons that are more related to the way of living of each, which rely on culture, beliefs and values that are shared collectively. This combination of individual and collective aspects, associated with other factors of different natures, such as emotional reactions caused by the confrontation of certain situations, or even understanding of the own life, helps to compose a picture statement how complex you think health and talking about a healthy way of life ". ${ }^{18}$

"The study of the interrelationship between mental stress and THERE is complex, because many other variables (genetic factors, diet, exercise, weight, etc.) may influence the onset of hypertension and should therefore be controlled in order to assess the real contribution of psycho emotional factors in the genesis of the disease. The difficulty in 
controlling these variables interacting can explain partly the variability of the reported findings. Another difficulty would be the quantification of stress ". ${ }^{3}$

The prevalence of high blood pressure can be up to five times higher in some groups of individuals who work or live in stressful situations, when compared with those away from these situations. Clinical observations suggest that hypertension and individuals with a predisposition to develop hypertension present more stress and respond differently to him. ${ }^{3}$, 11.37

\section{Sodium consumption}

The abuse in the use of salt (sodium chloride) in the feed was referenced by $11.0 \%$ of respondents. The HAS can have its pathological mechanism triggered by a genetic regulatory system hypersensitivity of the PA, which face the presence of medium or high amounts of salt and/or stress would cause the disease. In other words, just a continuous action of environmental factors (and stress) to cause the syndrome. ${ }^{21}$

Based on the above you can check the association between salt intake and stress among the subjects. Of the total, nearly $62.0 \%$ showed excess salt intake in the diet and still consider yourself stressed. In relation to gender, $77.0 \%$ of declared excessive consumption of salt were women, while $23.0 \%$ were men.

Next to the control of weight and regular physical activity, reduce salt intake is one of the measures of greater impact in the prevention of hypertension, are associated to the lower elevation annual PA. ${ }^{2}$

\section{Classification of blood pressure values of the subject}

The last of the stages of data analysis was the verification of the PA of the participants of the study. Table 4 demonstrates the ratings obtained in gauging the PA participants immediately after the interview.

Table 4: classification of the PA of the subject according to Ministry of health of Brazil (2006).

\begin{tabular}{lll}
\hline CLASSIFICATION & N & $\%$ \\
\hline Normal $(120 / 80<<)$ & 13 & 32.5 \\
Pre-hypertension $(120-139 / 80-89)$ & 20 & $50.0 \%$ \\
& & \\
\hline HYPERTENSION - & 6 & $15.0 \%$ \\
\hline Stage 1 (mild) $(140-159 / 90-99)$ & 1 & 2.5 \\
Stage 2 (moderate) $(\geq 160 / \geq 100)$ & \\
The highest value of systolic or diastolic established hypertensive \\
stage frame. Systolic and diastolic pressures were in different \\
categories, the biggest was used to stage classification. \\
\hline
\end{tabular}


SAH is proven to be a multifactorial condition. To better understand the landscape of multiple factors that interfere in the appearance of the disease, those individuals who have blood pressure changed from borderline classification had their quantified risk factors and grouped. Of those who had altered levels of PA, 17.0\% have shown up to two risk factors, $33.0 \%$ of three to four, and $50.0 \%$ have five to six risk factors.

The figures took into account only the numerical Association. Practical experience shows that hypertensive patients often have multiple risk factors, contributing to the syndromic of the complex HAS. This fact also noticed in the data obtained from the study.

\section{CONCLUSION}

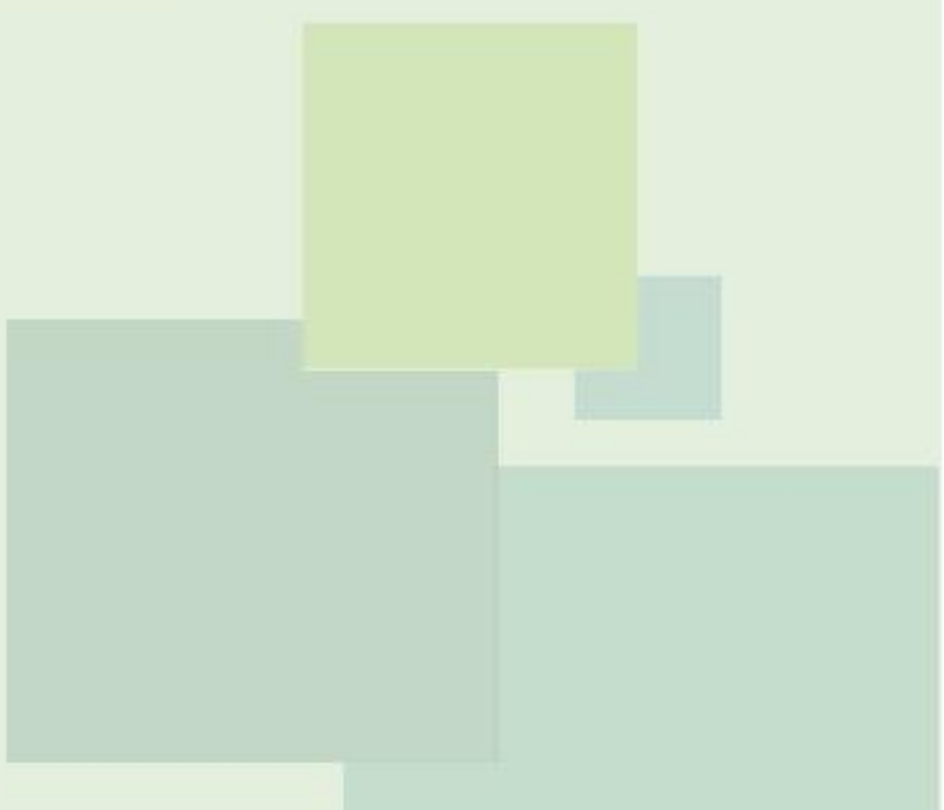

The study focused on SAH, ma chronic disease that affects thousands of people throughout the world. As every chronic disease, HAS no cure, but your body damage can be avoided. However, the onset of disease control-main target of multidisciplinary approach - is 
difficult, since the lifestyle of each individual must be known and encourage positive changes should be performed. So, for example: say a person who has always been sedentary that she needs to practice physical exercises may not cause major effects, to the extent that your body "used" with this condition. So, the challenge of prevention and control of the disease is to get people to understand your condition of sick and participate actively in this process, is avoiding dangerous habits or simply adhering to the proposed treatment. As well, even before the emergence of the disease the negative living habits to be controlled or eliminated.

The view that one should expect to get sick to be treated should eliminated from society, because even health professionals often influenced by system that meets the disease, ends up neglecting scientific knowledge and their capacity for planning and management on their own health.

With regard to the first objective of this work, various risk factors were identified in the study population. As for factors considered non-modifiable, a superiority of individuals of black ethnicity, women and young age (under 40 years). Of these three, only the color of the skin concern with respect to the emergence of HAS, because, although a large number of women, the age contributes to disease prevention. However, more than half of respondents have father and/or mother hypertensive. These factors identified cannot be avoided or prevented. However, there is a need for professionals to understand their genetic characteristics and to understand that the other risk factors for the disease are fertile ground in their bodies, a larger proportion than those who do not have them.

Modifiable risk factors, stress was the most encountered as appearing in the lifestyle of the professionals. Of these, a quarter of the total mentioned owning a daily life stressful. Secondly, the sedentary lifestyle appears with more than $20.0 \%$, close to the bad power supply military professionals declared. Stress, sedentary lifestyle and balanced nutrition seems to be a constant of daily life of the participants. Although a large number of sedentary and individuals who practice an unregulated diet, however the percentage of obese not reached $10.0 \%$.

Smoking was declared by $7.0 \%$ of respondents, being the largest portion of males. Many authors do not consider tobacco use as a risk factor for SAH and Yes as a prognostic factor for the disease. However, regardless of gender, the use of tobacco should be gradual and repeatedly discouraged through counseling and therapeutic measures of specific support.

Considering the gender, among women the use of hormonal contraceptives was $36.0 \%$. Of this percentage, few women are considered obese and/or smoked at the same time. Despite this, the hormonal changes in the body of women, that make this type of treatment, can lead to an increase in the number of hypertensive women two to three times compared to not using the medicine. Taking into account that the age of this population found itself in an average of 31 years, is easy to see that, if measures in the sense of stopping the use of hormonal contraceptives are taken, in some years the rate of hypertension in these women can rise exponentially.

The addition of salt in foods was not indicated as a constant habit. However, there is doubt regarding the actual amount of salt intake, because concepts of little, very average and vary from person to person. As well, studies should be conducted to find a homemade measure that expresses the values allowed for consumption. 
The alcoholism was the least risk factor cited by the subject. But, as in actual measurement of salt in food, is the question of the actual amount of intake of alcoholic beverages.

The data shows a dangerous lifestyle, which contribute to the incidence of SAH can be connected to numerous cardiovascular diseases, such as acute myocardial infarction and the AVE. In this way, the study showed that, if the lifestyle of professionals is not changed, HAS in this population is almost given!

As for the second objective, considering itself as a cutting point PA above $140 / 90 \mathrm{~mm}$ $\mathrm{Hg}$, individuals who presented to high levels met a range of almost $18.0 \%$. In Brazil, HAS reaches a share of $20 \%$ of the total population. That is, the data of the study confirm the national indexes for SAH. However, the concern is the presence of many risk factors for the disease.

Of all respondents, half mentioned more than five risk factors. And clinical practice demonstrates that, in hypertensive subjects is hardly just a risk factor present. Therefore, the pros need accurate guidelines studied the harmful aspects of HAS. These guidelines can be implemented through health education programs. The lectures on the subject, the distribution of pamphlets explaining the creation of regular events on prevention and control of frequent monitoring and risk factors with an emphasis on lifestyle modification, can be measures which will contribute to the search for a better quality of life for the professionals.

The contribution of military police institution and its subjects were of fundamental importance for the achievement and completion of this study. It is believed that the work will fund the other studies on the prevention and control of search HAS on workers. 


\section{REFERENCES}

1 Ministério da Saúde (Brasil). Secretaria de Atenção à Saúde. Departamento de Atenção Básica. Hipertensão arterial sistêmica para o Sistema Único de Saúde. Brasília: Ministério da Saúde, 2006. 2 Sociedade Brasileira de Cardiologia / Sociedade Brasileira de Hipertensão / Sociedade Brasileira de Nefrologia. VI Diretrizes Brasileiras de Hipertensão. Arq. Bras. Cardiol. 2010; 95 (1 supl.1): 151

3 Silva JLL, Souza SL. Fatores de risco para hipertensão arterial sistêmica versus estilo de vida docente. Rev. Eletr. Enferm. 2004; 6(3): 330-335.

4 Sociedade Brasileira de Cardiologia / Sociedade Brasileira de Hipertensão / Sociedade Brasileira de Nefrologia. III Consenso Brasileiro de Hipertensão Arterial. Arq Bras. Endocrinol Metab. 1999; 43(4): 257-286

5 Sociedade Mineira de Cardiologia. Hipertensão: assassina silenciosa. Interativa. 2009; 2(6): 5-7. 6 Borges BLC. Comprometimento da função renal em pacientes cadastrados no programa hiperdia do município de Dourados, Mato Grosso do Sul-Brasil, 2009 [dissertação]. Brasília: Universidade de Brasília; 2009.

7 Magrini DW, Martini JG. Hipertensión arterial: principales factores de riesgo modificables en la estrategia salud de la familia. Enferm. Glob. 2012; 11(26).

8 Lessa I. 0 adulto brasileiro e as doenças da modernidade: epidemiologia das doenças crônicas não-transmissíveis. Rio de Janeiro: Abrasco; 1998.

9 Sociedade Brasileira de Hipertensão. III Diretrizes para uso da monitorização ambulatorial da pressão arterial. Arq Bras Cardiol. 2001; 77(4): 384-389.

10 Smeltzer SC, Bare BG, Hinkle JL, Cheever KH. Histórico e cuidados aos pacientes com hipertensão. In: Brunner \& Suddarth tratado de enfermagem médico-cirúrgica. 11 Ed. Rio de Janeiro: Guanabara Koogan; 2009. p. 862-874.

11 Maia CO, Goldmeier S, Moraes MA, Boaz MR, Azzolin K. Fatores de risco modificáveis para doença arterial coronariana nos trabalhadores de enfermagem. Acta Paul Enferm. 2007; 20(2): 138-142.

12 Rio de Janeiro. Lei n. 443 , de $1^{\circ}$ de julho de 1981. Dispõe sobre o estatuto dos policiais militares do Estado do Rio de Janeiro e dá outras providências.

13 Manfroi A, Oliveira FA. Dificuldades de adesão ao tratamento na hipertensão arterial sistêmica: considerações a partir de um estudo qualitativo em uma unidade de atenção primária à saúde. Rev. Bras. Med. Fam. e Com. 2006; 2(7): 165-176.

14 Costa JMBS, Silva MRF, Carvalho EF. Avaliação da implantação da atenção à hipertensão arterial pelas equipes de saúde da família do município de Recife (PE, Brasil). Ciênc Saúde Coletiva. 2011; 16(2): 623-633.

15 Sociedade Brasileira de Cardiologia. III Diretrizes brasileiras sobre dislipidemia e diretriz de prevenção da aterosclerose do Departamento de Aterosclerose da Sociedade Brasileira de Cardiologia. Arq Bras. Cardiol. 2001: 77 (supl.3): 1-48.

16 Daher DV. Por detrás da chama da lâmpada. Niterói: Ed. UFF; 2000. 
17 Conselho Federal de Enfermagem. Comissão de Business Intelligence. Análise de dados dos profissionais de enfermagem existentes nos conselhos regionais. Brasília: Cofen; 2011.

18 Ministério da Saúde (Brasil). Secretaria de Políticas de Saúde. Departamento de Ações Programáticas Estratégicas. Plano de reorganização da atenção à hipertensão arterial e ao diabetes mellitus: hipertensão arterial e diabetes mellitus. Brasília: Ministério da Saúde; 2001.

19 Neves MF, Kasal DAB. O que dizem as diretrizes brasileira, americana, europeia e canadense em relação às metas? Rev. Bras. Hipertens. 2010; 17(3):178-181.

20 Martinez MC, Latorre MRDO. Fatores de risco para hipertensão arterial e diabete melito em trabalhadores de empresa metalúrgica e siderúrgica. Arq Bras. Cardiol. 2006; 87(4): 471-479.

21 Cesarino CB, Cipullo JP, Martin JFV et al. Prevalência e fatores sociodemográficos em hipertensos de São José do Rio Preto. Arq Bras Cardiol. 2008; 91(1):31-35.

22 Pereira M, Lunet N, Azevedo A, Barros H. Differences in prevalence, awareness, treatment and control of hypertension between developing and developed countries. J Hypertension. 2009; 27(5): 963-975.

23 Lessa I. Epidemiologia da hipertensão arterial sistêmica e insuficiência cardíaca no Brasil. Rev. Bras. Hipertens. 2001; 8(4): 383-92.

24 Fonseca RMGS. Equidade de gênero e saúde das mulheres. Rev. Esc. Enferm USP. 2005; 39(4): 450-459.

25 Irigoyen MC, Lacchini S, De Angelis K, Michelini LC. Fisiopatologia da hipertensão: o que avançamos? Rev. Soc Bras. Cardiol. Estado de São Paulo. 2003; 13(1): 20-45.

26 Praxedes RR. Cor e segregação no Brasil. Rev. Espaço Acadêmico. 2003; 3(27).

27 Cruz ICF, Lima R. Etnia negra: um estudo sobre a hipertensão arterial essencial e os fatores de risco cardiovasculares. Rev. Enferm UERJ. 1999; 7(1): 41-44.

28 Barreto-Filho JAS, Krieger JE. Genética e hipertensão arterial: conhecimento aplicado à prática clínica? Rev. Soc Bras. Cardiol Estado de São Paulo. 2003; 13(1): 46-55.

29 Rouquaryol MZ, Filho NA. Epidemiologia, história natural e prevenção de doenças. In:

Epidemiologia e saúde. 5 Ed. Rio de Janeiro: Médica e Científica; 2003. p. 15-31.

30 Leal CMS. Reavaliar o conceito de qualidade de vida. Universidade dos Açores; 2008.

31 Chasan-Taber L, Willet WC, Manson JE et al. Prospective study of oral contraceptives and hypertension among women in the United States. Circulation. 1996; 94(3): 483-489.

32 Lubianca JN, Faccin CS, Fuchs FD. Oral contraceptives: a risk factor for uncontrolled blood pressure among hypertensive women. Contraception. 2003; 67(1): 19-24.

33 Carvalho JGR. Hipertensão arterial secundária. Medicina Ribeirão Preto. 1996; 29: 220-231.

34 Friedewald W.T. Epidemiologia das doenças cardiovasculares. In: Gill et al. Cecil tratado de medicina interna. 20 Ed. Rio de Janeiro: Guanabara Koogan; 1997. p. 189-191

35 Oparil S. Hipertensão arterial. In: Gill et al. Cecil tratado de medicina interna. 20. ed. Rio de Janeiro: Guanabara Koogan; 1997. p. 285-301.

36 Nettina SM. Prática de enfermagem. 7 Ed. Rio de Janeiro: Guanabara Koogan; 2003.

37 Wenzel D, Souza JMP, Souza SB. Prevalência de hipertensão arterial em militares jovens e fatores associados. Rev. Saúde Pública. 2009; 43(5): 789-795.

38 Mano R. Manuais de cardiologia. Disponível em: www.manuaisde cardiologia.com/. Acessado em: 10, 15, 20, 21 e 27 de maio de 2006.

39 Brum PC, Silva GJJ, Moreira ED, Ida F, Negrão CE, Krieger EM. Exercise training increases baroreceptor gain sensitivity in normal and hypertensive rats. Hypertension. 2000; 36: 1018-1022. 
40 Townsend MC. Enfermagem psiquiátrica: conceitos de cuidados. 3 ed. Rio de Janeiro: Guanabara Koogan; 2002.

41 Lipp MEN. Controle do estresse e hipertensão arterial sistêmica. Rev. Bras. Hipertens. 2007; 14(2): 89-93.

42 Vicente NG, Ferreira LA, Rezende MP et al. Percepção do estresse ocupacional por bombeiros militares de uma cidade do interior de Minas Gerais. J. Res.: Fundam. Care. Online 2013. Jul./Set. 5(3):75-84.

43 Tibúrcio MP, Torres GV, Enders BC et al. Análise contextual da mensuração da pressão arterial na prática clínica. J. Res.: Fundam. Care. Online 2013. Jul./Set. 5(3):328-336.

Received on: 03/04/2014 Required for review: No Approved on: 17/09/2015 Published on: 07/01/2016
Contact of the corresponding author: Jorge Luiz Lima da Silva Universidade Federal Fluminense - Rua Dr. Celestino, 74, Niterói - RJ (21) 2629-9484 E-mail:jorgeluizlima@gmail.com 